Wojciech Siegień

ORCID: 0000-0002-6882-6250

Uniwersytet Gdański

wojciech.siegien@ug.edu.pl

\title{
Wyjść poza krąg. O przywracaniu pedagogiki Marii Rogowskiej-Falskiej i Wiery Schmidt
}

\section{Summary}

Move beyond the circle. On restoring the pedagogy of Maria Rogowska-Falska and Vera Schmidt

In the article, based on theoretical assumptions about framing mechanisms taken from the work of Georg Lakoff and the Polish tradition of post-dependence research, the author conducts a comparative analysis of cases of reframing the hegemonic and strongly patriarchal narratives regarding the pedagogical legacy of Janusz Korczak and Ivan Jermakov. As a result of systemic changes after 1989 , narratives so far suppressed have come to the fore. It applies to minority voices, especially female voices. The comparative analysis took into account the voices of female educators from Poland and the Soviet Union - Maria Rogowska-Falska and Vera Schmidt. The main questions concern how hegemonic pedagogical discourses may erode and whether the processes of redefining pedagogical thought in Poland are analogous to trends in other countries of Central and Eastern Europe? The study points to far-reaching analogies of the processes of reframing in Poland and Russia. This has its consequences for our understanding of the achievements of Janusz Korczak in Poland and the roots of psychoanalysis in the Soviet Union.

Keywords: Maria Rogowska-Falska, Vera Schmidt, Janusz Korczak, reframing, postdependence studies

Słowa kluczowe: Maria Rogowska-Falska, Wiera Schmidt, Janusz Korczak, przeramowanie, studia postzależnościowe

\section{Wstęp}

Wraz z transformacją polityczną wywołaną upadkiem bloku wschodniego w krajach postsocjalistycznych rozpoczęła się zmiana w obrębie nauki. Mam na myśli przede wszystkim redefinicje pól badawczych dyscyplin oraz ujawnienie nurtów krytycznych. Dobrym przykładem obrazującym te zmiany jest dyskurs etnologiczny w Polsce. Po ustaniu socjalistycznych stosunków dominacji antropolodzy krytycznie zwrócili się do korzeni dyscypliny. Doprowadziło to do wydobycia dotychczas nieobecnych lub zmarginalizowanych głosów. Ponownie odkryto prace takich badaczek, jak Maria Czaplicka czy Stefania Ulanowska (Rataj 2016). 
Inaczej spojrzano także na dotychczasowy dorobek tuzów polskiej etnografii. Okazało się, że Oskar Kolberg czy Zorian Dołęga-Chodakowski podpisywali swoimi nazwiskami materiały zbierane w dużej części przez bliskie im kobiety (Kubica 2018).

W wypadku refleksji o korzeniach myśli pedagogicznej można powiedzieć, że jej wschodnioeuropejski nurt wciąż pozostaje w orbicie oddziaływania nieprzewartościowanych i archetypicznych dyskursów. Jako przykład może posłużyć silnie ugruntowany w Polsce dyskurs Janusza Korczaka jako samodzielnego twórcy nowego nurtu w pedagogice. Podobnie rzecz się ma $\mathrm{z}$ hegemoniczną narracją o Antonie Makarence w byłych państwach Związku Sowieckiego czy o ojcach założycielach psychoanalizy w teorii wychowania.

\section{Pytania o zmianę}

Każdy rodzaj opresji rodzi opór. W moim tekście stawiam pytanie o to, w jaki sposób hegemoniczne dyskursy pedagogiczne mogą ulec erozji. Mam na myśli proces rozpadu jednopolarnej opowieści i pojawienie się szczelin, przez które przesączają się alternatywne narracje, zmieniające ustalony układ rzeczy. W moim wypadku jest to pytanie o postaci, ich biografie i głosy, które były poddane represji, a teraz mają szansę zaistnieć. Swoich zainteresowań nie ograniczam do Polski, interesuje mnie bowiem szerszy kontekst krajów postsocjalistycznych. Czy zatem procesy redefinicji myśli pedagogicznej w Polsce są zbieżne z tendencjami w innych krajach Europy Środkowej i Wschodniej?

Zakreślony przeze mnie szeroki kontekst obejmuje kraje postsocjalistyczne. Dlatego w pracy wykorzystałem metodę wielokrotnego studium przypadku w wariancie dla dwóch odmiennych tradycji naukowych, które jednak mieszą się w wyznaczonym kontekście ogólnym. Za Yin (2015: 89) zaznaczam, że ten rodzaj badań powinien się kierować logiką linearnej replikacji danych. Oznacza to, że dobór moich przypadków pomyślany jest tak, że zapowiada podobne wyniki. Jest to uzasadnione przede wszystkim liczbą analizowanych przypadków (dwa), która umożliwia właśnie ten rodzaj replikacji danych. Główną jednostką analityczną tej pracy są więc zastane i dostępne narracje o biografiach i dorobku dwóch wybranych osób: polskiej pedagożki Marii Rogowskiej-Falskiej oraz sowieckiej pionierki psychoanalitycznej szkoły wychowania Wiery Schmidt. Każda biografia będzie rozpatrywana w określonym kontekście kulturowym. W polskim wypadku będzie to narracja o spuściźnie Janusza Korczaka, a w sowieckim - o szkole psychoanalitycznej pedagogiki lat 20 . W toku mojego rozumowania wybór przypadków był ewokowany konkretnymi wydarzeniami.

\section{Ewokacja kontekstu polskiego}

Znany francuski filozof, uczeń Jacques'a Derridy i Louisa Althussera, Bernard-Henri Lévy odwiedził Gdańsk 12 kwietnia 2019 roku. W Europejskim Centrum Solidarności zaprezentował monodram Looking for Europe. Wchodząc w dialog z odradzającym się 
w Europie i Polsce nacjonalizmem, rasizmem i nienawiścią do innych ludzi, odwoływał się do demokratycznej spuścizny europejskiej oraz osób symbolizujących przeciwieństwo wymienionych barbaryzujących tendencji. Wśród takich nazwisk, jak Churchill, Picasso, Spinoza, Wałęsa i Wojtyła, wymienił jednego pedagoga - Janusza Korczaka. Odbywało się to długo po 2012 roku, ogłoszonym w Polsce Rokiem Korczakowskim. W czasie Roku Korczakowskiego w kraju opublikowano wiele prac na jego temat, zorganizowano różne działania edukacyjne. W pierwszym numerze „Kwartalnika Pedagogicznego” z tego roku w artykule otwierającym i dedykowanym temu wydarzeniu autorzy piszą: „mało jest w naszej tradycji postaci, które byłyby czczone jak właśnie on" (Jaczewski, Korbelak 2012: 15). Uznając ikoniczny status Korczaka dla polskiej myśli pedagogicznej, autorzy stawiają sobie za cel przywrócenie głosu osobom współtworzącym jego dorobek. Mowa jest o dwóch kobietach: Stefanii Wilczyńskiej i Marii Rogowskiej-Falskiej. W efekcie w jubileuszowym numerze każdej z pedagożek poświęcono stronę lakonicznej biografii.

\section{Ewokacja kontekstu sowieckiego}

W 2011 roku podczas Międzynarodowego Festiwalu Filmowego w Wenecji miał premierę film zatytułowany Niebezpieczna metoda (reż. Cronenberg, 2011). Film opowiada historię związku Zygmunta Freuda, Carla Junga oraz Sabiny Spielrein. Choć duża część tego obrazu jest poświęcona relacji między dwiema pomnikowymi postaciami psychoanalizy, po raz pierwszy w dyskursie popkulturowym pojawia się wyraźnie postać Spielrein - rosyjskiej Żydówki, pacjentki Junga, która następnie skończyła medycynę i sama zajęła się psychiatrią. Masowy odbiorca dowiedział się, że była to jedna z pierwszych psychoanalityczek pedagożek w Rosji. Po powrocie do Związku Sowieckiego przez pewien czas pracowała w eksperymentalnym przedszkolu w Moskwie, kierowanym przez Wierę Schmidt.

W ciągu roku po premierze filmu do księgarn w Rosji trafiają broszury autorstwa Wiery Schmidt. W większości są to niepublikowane teksty z lat 20. Prezentują zasady organizacji psychoanalitycznego eksperymentu wychowania zbiorowego - ewenementu w skali światowej, o którym szersza publika dowiaduje się po niemal stu latach. O unikatowości pracy zespołu pod kierownictwem Schmidt świadczy fakt, że klasyczny dla tradycji zachodniej psychoanalizy tekst opisujący eksperyment grupowej terapii i wychowania autorstwa Anny Freud i Sophie Dann opublikowano prawie 30 lat po powstaniu prac Wiery Schmidt (Freud, Dann 1951: 127-168).

\section{Narzędzia analizy}

W swojej analizie odwołuję się do pojęcia „ramowanie” (oraz przeramowanie), zaczerpniętego z prac Georga Lakoffa, zainspirowanego myślą Ervinga Goffmana (2010). Mechanizm ramowania jest naturalną cechą języka, elementem „zdrowego rozsądku” i oznacza przyporządkowanie zjawiskom określonych znaczeń (Lakoff 2011: 167). Dzięki niemu kształtują się zasady społeczne i instytucje, które powołujemy do wprowadzania tych za- 
sad. Konsekwencją działania mechanizmu ramowania jest narzucenie określonej wersji języka - a więc światopoglądu - innym. Dzieje się tak, dlatego że podstawą naszego myślenia są idee, których nośnikiem jest język. Przez użycie określonego języka idee zagnieżdżają się w naszym umyśle, a w wyniku naturalizacji przyjmujemy je jako własne (Lakoff 2011: 31).

Nie oznacza to, że jesteśmy zdeterminowani przez ramowanie - istnieje możliwość zmiany, a więc przeramowania. Oznacza to nie tylko zmianę ram odniesienia, zmianę struktur językowych, ale i zmianę społeczną. Lingwistyka kognitywna Lakoffa zajmuje się analizą powszechnego użycia języka. Nieodłączną częścią tego działania jest badanie pojęć i dyskursu politycznego (Lakoff 2017: 21). Przyjmuję, że nauki społeczne, szczególnie nauki edukacyjne, są ważną składową dyskursu politycznego (Mouffe 2008; Schmidt 2012).

Swoją analizę zakotwiczam także w pojęciach zaczerpniętych $\mathrm{z}$ teorii postzależnościowych, rozwijanych przez autorów i autorki z kręgu Centrum Badań Dyskursów Postzależnościowych. Odwołują się oni/one do tradycji studiów nad postsocjalizmem i krytyki postkolonialnej. Przyjmuję, że teorie postzależnościowe i proces przeramowania są wzajemne przystające. Punktem stycznym jest pojęcie czasu postzależnościowego. Hanna Gosk pisze, że ten czas zaczyna płynąć po ustaniu realnie istniejącej relacji podporządkowany-dominujący (Gosk 2014: 303). W najnowszej historii Polski można wskazać dwa momenty zerwania takiej relacji: lata 1918 i 1989. Według autorki jedną z cech tego czasu jest nienaturalność semantyczna - nie musi płynąć tylko do przodu i najistotniejsza staje się przeszłość oraz nie jest to czas neutralny ideowo. Wprost przeciwnie - to konstrukt polityczny, efekt pracy polityki historycznej, być może najsilniej wpływającej właśnie na sferę edukacji (Gosk 2014: 304). Przejawem konstrukcyjnego charakteru czasu postzależnościowego są narodowe rocznice historyczne, w których w pełni ujawnia się proces konstrukcji pamięci zbiorowej. W ostatnich latach najciekawsze zmiany pamięci zbiorowej w Polsce dotyczyły tzw. żołnierzy wyklętych (Dąbrowski, Troebst 2015; Korbiela 2016). Odwołując się do teorii postzależnościowych, zwracam też uwagę na kategorie wypracowane w obrębie krytyki feministycznej z centralnymi dla niej problemami płci, opresji, zależności oraz problemu ich zróżnicowania kulturowego, klasowego, narodowego czy w końcu - rasowego (Graczyk i in. 2015: 11). Takie ujęcie teoretycznie jest nieobce polskiej krytyce postzależnościowej, szczególnie tej skupionej na problematyce doświadczeń kobiet w środkowoeuropejskim kontekście kulturowym (Olechowska 2015: 365-377).

\section{Przywracanie zapomnianych glosów}

\section{Maria Rogowska-Falska}

Myślę, że zwrot w hegemonicznym dyskursie o spuściźnie Janusza Korczaka w Polsce przyszedł wraz z dyskusją wokół książki Magdaleny Kicińskiej Pani Stefa (Kicińska 2015), która pojawiła się po głośnej biografii Korczak. Próba biografii Joanny Olczak-Ronikier 
$(2011)^{1}$. Przywracanie głosu pedagożce rozpoczyna się paradoksalnie od konstatacji ciszy lub inaczej - niemówienia. Kicińska otwiera biografię Stefani Wilczyńskiej, bliskiej współpracowniczki Korczaka w Domu Sierot, opisem wizyty u jednego z jej wychowanków, Szlojme Nadela. Starszy pan stara się przypomnieć Wilczyńską: ,żyła tak, że mało o niej wiedzieliśmy, taka... niebyła. Nic po niej nie zostało, jakby jej nigdy nie było" (Kicińska 2015: 22). Te słowa najpełniej obrazują nieobecność biografii i głosu osoby, która faktycznie prowadziła na co dzień Dom Sierot. Analogicznie, wydobywając postać Wilczyńskiej ze sfery milczenia, Kicińska z rozmysłem buduje jej opis, nie tylko pokazując to, co wiemy o życiu bohaterki, ale też to, czego o niej nie wiadomo. Stefania Wilczyńska, ogólnie niedoreprezentowana w publicznym dyskursie o Korczaku, dopiero w czasach postzależnościowych odzyskuje należne miejsce w historii myśli pedagogicznej, przyczyniając się do przeramowania polskiego rozumienia spuścizny Janusza Korczaka.

$\mathrm{Na}$ tym tle inaczej rysuje się postać Marii Rogowskiej-Falskiej, pedagożki, która od 1919 roku prowadziła w Pruszkowie i na Bielanach zakład wychowawczy dla sierot z rodzin robotniczych „Nasz Dom”. Organizacja zakładu inspirowana była założeniami Korczaka, który do konfliktu z Falską w 1936 roku współpracował z placówką. W literaturze można znaleźć jej lakoniczną biografię, często na marginesach życia męża lub brata Bronisława, ale najczęściej pojawia się ona jako postać epizodyczna w wielkiej narracji o Korczaku. Olczak-Ronikier opisuje jego pobyt w Kijowie w 1915 roku, gdzie po raz pierwszy spotkał Marinę Falską. W trakcie trzydniowego urlopu z armii Korczak dociera do Kijowa, odwiedza kilka instytucji, aż zostaje skierowany do Falskiej, która już wtedy prowadzi internat dla 60 sierot wojennych. Tam zdoła ustanowić samorząd, sąd, założyć gazetkę i ma jeszcze czas, żeby powrócić do jednostki wojskowej. Przelotne spotkanie w Kijowie, a potem współpraca pedagogów w „Naszym Domu” staje się podstawą uznania Falskiej wraz ze Stefanią Wilczyńską za „kobiety z kręgu Korczaka”. Chociaż pedagożka na co dzień mieszkała i pracowała wraz z dziećmi w „Naszym Domu”, produkowała ogromną ilość materiału badawczego, w historycznym dyskursie staje się postacią nawet nie drugiego, lecz trzeciego planu, swego rodzaju aktantem-przedmiotem (Ball 1997: 198). A przecież mamy do czynienia z osobą, która w 1915 roku już od wielu lat była zaangażowana $\mathrm{w}$ pracę wychowawczą i społeczną. Skończyła studia pedagogiczne, pracowała w eksperymentalnych instytucjach edukacji elementarnej, zakładała czytelnie robotnicze i angażowała się w alfabetyzację, była bliską znajomą rodziny Piłsudskich, działała w Polskiej Partii Socjalistycznej (PPS), prowadziła nielegalne drukarnie, miała na koncie odsiadkę na Pawiaku w tzw. Serbii i odbyty wyrok kilkuletniego zesłania do Wołogdy, po czym w dramatycznych okolicznościach utraciła męża i córkę.

Głos Marii Rogowskiej-Falskiej dla współczesnych odbiorców przywróciły w ostatnich latach powtórne wydania jej broszur oraz opis działalności „Naszego Domu” (Rogowska-Falska i in. 2007; Rogowska-Falska 2014a, 2014b). Czytając jej teksty, ma się

\footnotetext{
1 Należy wspomnieć, że pojawiały się wcześniejsze publikacje, w których była mowa o Stefanii Wilczyńskiej (zob. Puszkin, Ciesielska 2004). Książka Kicińskiej jest jednak pierwszą pełną biografią. Przykład nieudanego przeramowania zob. Pyrzyk (2015).
} 
jednak wrażenie nieobecności autorki. Dopiero ze wstępu Korczaka do Wspomnień z maleńkości dowiadujemy się o kluczowej roli Marii Falskiej w spisywaniu dziecięcych wspomnień wychowanków „Naszego Domu”. Jak wskazuje Jakubiak (2011: 17), ten rodzaj obserwacji rozwoju dzieci był charakterystyczny dla konstytuującej się wtedy pedologii, a korzenie podobnych założeń metodologicznych sięgają XIX wieku.

Głos Falskiej jest niejako udzielony przez Korczaka, ale trzeba pamiętać, że jest to autonomiczny głos badaczki, która wnosi swoje korekty do pracy pedagogicznej. Z mojego puntu widzenia najciekawsze są te elementy jej klinicznych studiów wychowanków, w których podczas indywidualnych sesji notuje fantazmatyczne wspomnienia i sny. Prosi też dzieci o wykonywanie rysunków. Podczas sesji nikt nie może być obecny, drzwi od gabinetu muszą być zamknięte. Ten rodzaj pracy z wychowankami przywołuje na myśl praktykę terapeutyczną rozwijaną w owym czasie przez badaczy $\mathrm{z}$ kręgu teorii relacji z obiektem, w której wykorzystywano mechanizm projekcji. Zacytuję dwie transkrypcje sesji, które dobrze obrazują, z jakim materiałem pracowała Falska. Pierwsza jest zapisem głosu Józia:

A przy tej kamienicy stała fabryka naszego gospodarza - powózków i kuchni i aeroplan niemiecki chciał puścić bombę na fabrykę i się nie udało i bomba wpadła na szyld ogrodu. Wtenczas przechodziła dziewczynka i odłamek bomby uderzył ją w rękę i ona się przewróciła. Jeden mężczyzna doskoczył, ścisnął jej mocno rękę i ten odłamek wyszedł jej z ręki. Przez ten przestrach moja mama straciła władzę w ręku (Rogowska-Falska i in. 2007: 45).

Uderzające w tym fragmencie jest to, że Falska zanotowała faktycznie dziecięcy opis nerwicowej reakcji dysocjacyjnej, charakterystycznej dla zaburzeń, które dzisiaj nazywamy somatoformicznymi, a które były szczególnym obiektem zainteresowania psychiatrów na początku XX wieku.

Jednym z ciekawszych przypadków jest studium chłopca Leonarda, uciążliwego przybysza i ,stawiaka”, jak go nazywały dzieci. Pedagożka notuje jego sen:

To mi się śniła mama. Że była mamusia w piekle, a ja mamusię goniłem. I od razu mamusia do kotła, gdzie się pieką dusze wskoczyła. Ja mamusię złapałem i do nieba prowadziłem. Wyrywała się, ale trzymałem mocno. Nie chciała iść do nieba. Co w niebie jest? Taki ogród. A w tym ogrodzie owoce rozmaite. Gruszki. Same słodycze. Ja jadłem te słodycze - mamusia nie chciała jeść. To ja wziąłem rękę mamusi i mamusia rwała i jadła. A później na niebie gwiazdy się palili i anioły na trąbach grali. I jak oni grali, to wtedy najstarszy Lucyper z piekła przyszedł, chciał zagrać. A ja nie dałem. „Coś ty w niebie robił?” (MF) Ja umarłem. I moja mamusia umarła. Ja byłem aniołem w niebie, a mamusia w piekle. Ja byłem najstarszym aniołem w niebie. I anioły mnie pozwolili wyjść z nieba po mamusię. I mamusia już była w niebie. Koniec. Już (Rogowska-Falska i in. 2007: 205-206).

Studium Leonarda jest obszerne i zawiera wiele szczegółowych informacji dotyczących zachowania chłopca. $\mathrm{Z}$ pewnością mamy do czynienia z chłopcem z zaburzeniami 
zachowania, w sferze fantazmatycznej ujawniającego silną potrzebę omnipotencji. Przywołuję te fragmenty, gdyż wskazują na inspiracje metodologiczne zaczerpnięte z psychoanalizy. Opis przypadku Leonarda kończy stwierdzenie: „Jest to materiał, który może być opracowany przez specjalistę pedagoga, może przez psychoanalityka" (Rogowska-Falska i in. 2007: 226).

Igor Newerly, wspominając Marię Falską, pisze, że jej życie wiedzie w głąb czasu i stosunków (Newerly 1966: 174). Jeśli wykorzystać jej dorobek w procesie przeramowania, to można jej biografię wyrwać $\mathrm{z}$ hegemonii mitu Korczakowskiego lub metaforycznie z grona „kobiet z kręgu Korczaka” i wpisać ją w szersze tendencje pedagogiczne i psychologiczne początku XX wieku. Nawiasem mówiąc, sama Falska pisała w 1933 roku w liście do Jana Pęcińskiego: „Zetknęłam się z Korczakiem. Ujrzałam cel. Moim on nie stał się nigdy. Inna struktura psychiczna”. Przed wojną zaś uznawała, że eksperyment Korczaka się nie powiódł. Nawiązując bezpośrednio do metafory głębi czasu i stosunków Newerlego, należy wydobyć na powierzchnię formatywne inspiracje Falskiej, inne niż Korczakowskie. Poza otwarciem na nowe wtedy tendencje psychoanalityczne, widoczne w zainteresowaniu życiem fantazmatycznym dzieci i studiami nad traumą dziecięcą, można wskazać zainteresowanie przede wszystkim pismami Edwarda Abramowskiego, ale też tołstoizmem. Ponadto Falska wspomina ogromne wrażenie, jakie wywarła na niej twórczość Stefana Żeromskiego. W tym sensie Maria Rogowska-Falska była kobietą nie tyle z kręgu Korczaka, ile autonomicznie działającą pedagożką z kręgu socjalistycznie $i$ anarchistycznie zorientowanej radykalnej inteligencji polskiej początku XX wieku.

\section{Wiera Schmidt}

W 2012 roku w Rosji ukazuje się praca Wiery Schmidt zatytułowana Psychoanalityczne wychowanie $w$ sowieckiej Rosji. Jest to thumaczenie wykładu autorstwa Schmidt, przygotowanego dla Zygmunta Freuda z okazji zjazdu Międzynarodowego Towarzystwa Psychoanalitycznego w Zurychu w 1923 roku. W tomie znajduje się lakoniczna, jednostronicowa biografia Wiery Schmidt. Dla szerszego odbiorcy rosyjskojęzycznego jest to pierwsza szansa zapoznania się z pismami pionierki psychoanalitycznego wychowania w ZSRS. Należy podkreślić, że na thumaczenie tej pracy na język rosyjski trzeba było czekać 90 lat.

Przeramowanie, o którym mówię w kontekście dorobku Falskiej i tradycji Korczakowskiej w Polsce, wpisuje się zatem w szerszą tendencję w naukach społecznych w tej części Europy. Porównując ze sobą polski i rosyjski kontekst, zauważamy uderzające zbieżności w pomijanych latami biografiach pedagożek. Po pierwsze zwraca uwagę marginalna pozycja Schmidt w sankcjonowanych do tej pory narracjach o psychoanalizie w Związku Sowieckim. W nich hegemoniczną rolę odgrywał Iwan Jermakow, psychiatra, założyciel Rosyjskiego Towarzystwa Psychoanalitycznego, którego wskazywano jako kierownika wielu inicjatyw tego kręgu. Ważnym elementem spuścizny Towarzystwa jest eksperyment wychowawczy w przedszkolu-laboratorium „Międzynarodowa Solidarność”, który 
był faktycznie prowadzony przez Wierę Schmidt. Podobnie jak w wypadku „,kobiet z kręgu Korczaka", codzienna praca organizacyjna i badawcza laboratorium spoczywała na pozbawionych do niedawna możliwości mówienia pedagożkach. Zaskakująco podobne w tych dwóch kontekstach są też metody pracy analitycznej i cele. Definiując kodeks pracy pedagoga w swoim laboratorium, Schmidt podkreśla, że praca pedagogiczna powinna opierać się nie tyle na teoretycznych założeniach (w tym wypadku dotyczących seksualnego rozwoju dziecka i mechanizmów przeniesieniowych), a raczej na materiale obserwacyjnym, pozyskiwanym $\mathrm{w}$ trakcie codziennych interakcji z dziećmi (Schmidt 2011: 24). Poza podstawowym celem wychowania, definiowanym jako przystosowanie dziecka do wymagań rzeczywistości, Schmidt podkreślała potrzebę sublimacji infantylnych impulsów popędowych dzieci, co jest spójne z twierdzeniami Abramowskiego dotyczącymi istoty przeobrażeń etycznych jednostki jako warunku zmiany społecznej.

W swojej pracy Dzieci mówia Schmidt (2012) zamieściła wiele obserwacji, spośród których przytoczę jedną. Dotyczy trzyletnich dzieci: Liki i Alika, które w trakcie leśnej przechadzki wybierały „naj-, największe kije”. Schmidt notuje:

Lika: Alik, chodź, pomóż mi znaleźć jak największą pałkę! Idą razem do lasu. Nagle słychać ich radosne, triumfalne okrzyki. Po pewnym czasie słyszę: mamo, pomóż nam. Podchodzę. Na ziemi leży ścięta brzoza wielkości kilku metrów. Dzieci próbują ją podnieść i proszą mnie o pomoc. Długo nie mogą uwierzyć, że nie mogę jej podnieść ani nawet ruszyć jej z miejsca (Schmidt 2012: 40).

Podobnie jak w „Naszym Domu”, w „Międzynarodowej Solidarności” obserwacji podlegały wszystkie aspekty funkcjonowania dzieci. Prowadzono drobiazgową dokumentację ich rozwoju. Chociaż sytuacja psychologiczna i rodzinna dzieci moskiewskich była inna niż polskich (dzieci w laboratorium Schmidt nie były tak traumatyzowane, jak podopieczni Falskiej), notowane obserwacje dotyczą podobnych zjawisk rozwojowych. Obydwie badaczki zwracały uwagę na fantazmatyczną stronę funkcjonowania dzieci, dlatego też - jak w przytoczonym przypadku - skupily się na omnipotentnych fantazjach dziecięcych.

Jeśli odwołać się do mechanizmu przeramowania silnie androcentrycznych dyskursów pedagogicznych, to porównanie wskazuje na ścisłą chronologiczną zbieżność nasilenia tego procesu w obydwu kontekstach. Zmiana ram, która pozwoliła na zaistnienie głosu Schmidt we współczesnej Rosji, jest elementem szerszego procesu przeramowania w dyskursie psychologicznym i pedagogicznym, zainicjowanego po rozpadzie ZSRS - a więc rosyjskiego wariantu czasu postzależnościowego. Od lat 30. XX wieku, czyli od momentu utrwalenia się stalinizmu, aż do lat 90 . w oficjalnym obiegu naukowym psychoanaliza była zakazana (Etkind 1993: 213-268). Aleksandr Łuria mógł być więc znanym na całym świecie neuropsychologiem, ale niewielu wiedziało, że zaczynał karierę w przedszkolu-laboratorium pod kierownictwem Schmidt, a jego pierwszy tekst dotyczył psychoanalizy (Łuria 1925: 47-80). Dodatkowo zwracam uwagę na mechanizm redefinicji ram mówienia o pedagogice inspirowanej psychoanalizą, dla którego wyzwalaczem było wydarze- 
nie spoza dziedziny, a mianowicie sukces filmu Niebezpieczna metoda. Tak więc to film zainicjował publiczną dyskusję o roli kobiet w historii dziedziny. Można powiedzieć, że w procesie zwrócenia się do przeszłości, jako cesze czasu postzależnościowego, redefinicja i pełnoprawne włączenie kobiecych biografii i ich głosów do oficjalnej wersji dyskursu genealogicznego pedagogiki zachodzi na jego późnych etapach.

\section{Zakończenie}

Pedagożki Maria Rogowska-Falska i Wiera Schmidt były aktywne w różnych kontekstach kulturowych, ale w podobnym czasie. Socjalistyczne zaangażowanie Falskiej korespondowało z ideologicznym oddaniem dla budowy komunizmu Schmidt. Być może właśnie radykalizm ideologiczny wpłynął na ich nieprzeciętne poświęcenie pracy pedagogicznej. Chociaż obydwie pedagożki odpowiadały za prowadzenie domów dla dzieci i obszernych badań, a w połowie lat 20 . opublikowały swoje teksty, ich głosy zostały zdominowane i uciszone w pedagogicznym dyskursie na prawie 90 lat. W obydwu przypadkach można mówić o zdominowaniu przez patriarchalne narracje pedagogiczne, budowane wokół archetypicznych postaci męskich. Porównanie sposobów mówienia o roli pedagożek pokazuje, że w sytuacji politycznej monopolizacji narracji naukowej w czasie sprzed 1989 roku nie było możliwości redefinicji ich wkładu w rozwój myśli pedagogicznej. Dopiero z nadejściem czasu postzależnościowego, z jego świadomie politycznym zwrotem ku przeszłości i zmianą społeczną skierowaną na emancypację głosów mniejszościowych, w tym kobiecych, doszło do przeramowania hegemonicznych dyskursów o „,wielkich ojcach pedagogiki”, takich jak Janusz Korczak czy Iwan Jermakow oraz „ich kręgu”. Zaznaczę, że w obydwu kontekstach odbyło się to prawie symultanicznie - w kilkanaście lat po upadku bloku wschodniego. Na koniec chcę podkreślić, że zmiany były wywołane i wspomagane przez kulturowe impulsy, które pochodziły spoza dziedziny pedagogiki wywodziły z obszaru kultury masowej, gdzie krytycznej rewizji podjęli się pisarze, reżyserzy, dziennikarze i politycy. Być może jest to najlepszy dowód na erozję ram czasu zależności i upowszechnienie pluralizmu.

\section{Literatura}

Ball M. (1997), Narratology. Introduction to the Theory of Narrative. Toronto, University of Toronto Press.

Dąbrowski P.M., Troebst S. (2015), O używaniu i nadużywaniu historii. Polityka historyczna i kultury pamięci w Europie Środkowo- i Poludniowo-Wschodniej. „Pamięć i Sprawiedliwość”, 1(25).

Etkind A. (1993), Eros nevozmozhnogo. Istoria psikhoanaliza v Rossii. St. Petersburg, Meduza.

Freud A., Dann S. (1951), An Experiment in Group Upbringing. „The Psychoanalytic Study of the Child", 6(1).

Goffman E. (2010), Analiza ramowa. Esej z organizacji doświadczenia. Kraków, Zakład Wydawniczy Nomos. 
Gosk H. (2014), Postzależnościowe cechy czasu postzależności. Przypadek wspótczesnej prozy polskiej. W: H. Gosk, D. Kołodziejczyk (red.), Historie, społeczeństwa, przestrzenie dialogu. Studia postależnościowe w perspektywie porównawczej. Kraków, Universitas.

Graczyk E., Graban-Pomirska M., Horodecka M., Żółkoś M. (2015), Białe maski/ szare twarze. Ciało, pamięć, performatywność w perspektywie postzależnościowej. Kraków, Universitas.

Jaczewski A., Korbelak M. (2012), Korczak - w roku jemu poświęconym... „Kwartalnik Pedagogiczny", 1(223).

Jakubiak K. (2011), Od idei poznania dziecka do pedologii jako nauki o dziecku. „Problemy Wczesnej Edukacji”, 2(29).

Kicińska M. (2015), Pani Stefa. Wołowiec, Wydawnictwo Czarne.

Korbiela M. (2016), Polska pamięć autobiograficzna. „Teksty Drugie”, 6.

Kubica G. (2018), Kobiety i (nie)obecność problematyki ptci i gender w polskim ludoznawstwie i antropologii spoleczno-kulturowej. Szkic historyczno-autoetnograficzny. „Lud”, 102.

Lakoff G. (2011), Nie myśl o stoniu. Jak język ksztattuje politykę. Warszawa, Oficyna Wydawnicza Łośgraf.

Lakoff G. (2017), Polityka moralna. Jak myśla liberatowie i konserwatyści. Warszawa, Wydawnictwo Aletheia.

Łuria A. (1925), Psikhoanaliz kak sistema monicheskoy psikhologii. W: K.N. Kornilov (red.), Psikhologia i marksizm. Leningrad-Moskwa, Gosudarstvennoye izdatelstvo.

Mouffe Ch. (2008), Polityczność. Przewodnik Krytyki Politycznej. Warszawa, Wydawnictwo Krytyki Politycznej.

Newerly I. (1966), Żywe wiązanie. Warszawa, Czytelnik.

Olczak-Ronikier J. (2011), Korczak. Próba biografii. Warszawa, W.A.B.

Olechowska P. (2015), Dominacja i strategie oporu we współczesnej prozie ukraińskiej. W: E. Graczyk, M. Graban-Pomirska, M. Horodecka, M. Żółkoś (red.), Białe maski/ szare twarze. Ciało, pamięć, performatywność w perspektywie postzależnościowej. Kraków, Universitas.

Puszkin B., Ciesielska M. (2004), Stowo do dzieci i wychowawców. Stefania Wilczyńska. Warszawa, Muzeum Historyczne m.st. Warszawy.

Pyrzyk I. (2015), Aktualność pedagogii oraz pedagogiki Janusza Korczaka i Stefanii Wilczyńskiej. Włocławek, Wyższa Szkoła Humanistyczno-Ekonomiczna we Włocławku.

Rogowska-Falska M. (2014a), Zakład wychowawczy „,Nasz Dom”. Pruszków, Książnica Pruszkowska im. Henryka Sienkiewicza.

Rogowska-Falska M. (2014b), Wspomnienia z maleńkości: dzieci „Naszego Domu”w Pruszkowie. Pruszków, Książnica Pruszkowska im. Henryka Sienkiewicza.

Rogowska-Falska M., Kopczyńska-Ciesielska M., Puszkin B. (2007), Nasz dom: zrozumieć, porozumieć się, poznać. Warszawa, Muzeum Historyczne m.st. Warszawy.

Ratajczak A. (2016), Stefania Ulanowska. Tajemniczy życiorys, niepublikowane fragmenty twórczości. Białystok, Książnica Podlaska im. Łukasza Górnickiego w Białymstoku, Katedra Badań Filologicznych „Wschód-Zachód”, Uniwersytet w Białymstoku, Stowarzyszenie Naukowe „Oikoumene”.

Schmidt V. (2011), Psykhoanalitichieskoe vospitanie v Sovietskoy Rossii. Izhevsk, ERGO.

Schmidt V. (2012), Dieti govoriat. Izhevsk, EGRO.

Schmitt C. (2012), Teologia polityczna i inne pisma. Warszawa, Wydawnictwo Aletheia.

Yin K.R. (2015), Studium przypadku w badaniach naukowych: projektowanie i metody. Kraków, Wydawnictwo Uniwersytetu Jagiellońskiego. 